\title{
Different effects of crystals on release of inflammatory mediators from human peripheral blood phagocytic cells
}

\author{
PAUL DIEPPE, JUNE HORNBY, AND ANGELA SWAN \\ From the University Department of Medicine, Bristol Royal Infirmary, Bristol BS2 8HW
}

\begin{abstract}
Although the mechanism of crystal-induced inflammation remains disputed, most authors think that particle phagocytosis by polymorphonuclear cells (PMNs) has a central role. ${ }^{1}$ (P Platt and W C Dick, p. 4). PMNs are often thought of as indiscriminate cells, which release a package of mediators irrespective of the stimulus, ${ }^{2}$ but most experimental work on particles has only been with urate crystals. ${ }^{3}$ We have therefore examined phagocytosis, cell killing, enzyme release, and generation of chemotactic factor by human peripheral blood PMNs in response to four different crystals.

PMNs were obtained by Dextran separation of human venous blood. They were incubated in protein-free medium alone or with crystals of diamond (courtesy of De Beers, London; $5 \mu \mathrm{m}$ diameter), silica (courtesy of Pneumoconiosis Unit, Cardiff; $10 \mu \mathrm{m}$ long), monosodium urate monohydrate (5-10 $\mu \mathrm{m}$ long),
\end{abstract}

and hydroxyapatite (clusters about 2 $\mu \mathrm{m}$ diameter). The urate and apatite crystals were manufactured by standard methods. Phagocytosis and cell death were assessed visually and with trypan blue staining. $\boldsymbol{\beta}$-glucoronidase release was measured spectrophotometrically and expressed as a percentage of release by total cell lysis. Chemotactic factor generation was measured by a modified Boyden chamber technique using ZAS as a positive control.

All the particles were readily phagocytosed. The Table shows the different effects on cell viability, $\beta$-glucoronidase release, and generation of chemotactic factor. Diamond had little effect on cells, silica and hydroxyapatite caused a lot of cell death, hydroxyapatite caused most enzyme release, and urate the most generation of chemotactic factor.

CONCLUSIONS

These experiments must be interpreted cautiously in view of the difficulty in comparing different crystals (P A Dieppe et al., p. 60). However, they suggest that:

(1) Particle phagocytosis by PMNs may cause no cell damage or release of mediators-for example, diamond.

(2) Hydroxyapatite crystals are very toxic to phagocytic cells and cause release of a large quantity of enzymes.

(3) Urate crystals are more active in the generation of a PMN chemotactic factor than the other particles tested.

Although part of the difference could be accounted for by contamination of crystals or the presence of some mononuclear cells, these data suggest that PMNs respond quite differently to different particles. This may help to explain some of the variation in inflammatory responses to different crystals, and is being explored further.

We would like to acknowledge the financial support of the Arthritis and Rheumatism Council.

\section{References}

1 Phelps P, McCarty D J. Crystal induced inflammation in canine joints: the importance of polymorphonuclear leucocytes. $J$ Exp Med 1966; 124: 115-26.

2 Smolen J E, Wiessman G. Polymorphonuclear leucocytes. In: McCarty D J, ed. Arthritis and allied conditions. 9th ed. Philadelphia: Lea and Febiger, 1979: 282-95.

3 Dieppe P A, Doherty M. The role of particles in the pathogenesis of joint disease. In: Berry C L, ed. Current topics in pathology. Vol 71. Berlin: Springer Verlag, 1982: 200-33. 